\title{
Perception, Prevalence and Awareness of Sexual Harassment among University Students in Abbottabad
}

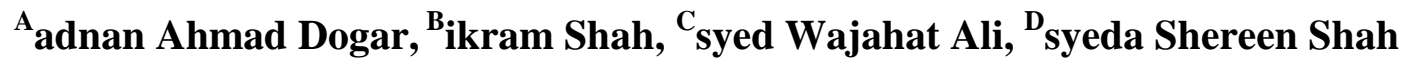 \\ a,b,d Department of Development Studies, COMSATS University Islamabad, Abbottabad Campus; \\ ${ }^{c}$ National Defence University, Islamabad
}

\section{ABSTRACT}

Policy guidelines against sexual harassment in institutions of Higher Learning were introduced in 128 public sector universities across Pakistan in January 2011. However, there has been an increase in the number of reported cases of sexual harassment that became prominent in mainstream media, so the institutional mechanism and the official definition of sexual harassment still needs a lot of clarity. The study aims to investigate the perception, prevalence and awareness of sexual harassment among university students along with possible causes of underreporting of the incidents of sexual harassment. Stratified random sampling and purposive sampling were used for data collection from students and members of sexual harassment committees respectively. The research findings revealed that sexual harassment at campus is a common phenomenon although majority of the cases go unreported owing to different institutional and cultural constraints. Instead of reporting to university administration, students adopt self adjustment mechanism by reducing the stay at campus or reducing the possibility of contact with males. There is dire need of more awareness sessions about what is sexual harassment and what students can do to deal with it.

Keywords

Sexual harassment; perception building; impact; university students; empowerment

Article Received: 18 October 2020, Revised: 3 November 2020, Accepted: 24 December 2020

\section{Introduction}

Sexual harassment can be defined as "unwanted sex-related behaviors that are appraised by the recipient as offensive and that exceed one's coping resources or threaten one's well-being. This includes unwelcome verbal and non-verbal sexual behaviors, as well as undesired physical behaviors that the target finds difficult to cope with or to handle". In social science the term is defined in three subtypes of sexual harassment behaviors: gender harassment, unwanted sexual attention, and sexual coercion (Schneider, Pryor, \& Fitzgerald, 2010). Gender harassment is defined as verbal and nonverbal gender-based behaviors that are insulting, hostile, and degrading. Unwanted sexual attention is considered any unwanted sexual behavior that is deemed offensive to the target. Hostile environment claims frequently involve gender harassment and unwanted sexual attention. Finally, in sexual coercion, sexual cooperation is extorted via promises of benefits (e.g., promotions, raises, better grades) or threats (e.g., failing a class, being fired). In addition, as compare to men, women report sexual harassment at a significantly higher frequency (Berdahl, 2007; Cortina \& Berdahl, 2008; Cortina et al., 2002; McLaughlin, Uggen, \& Blackstone, 2012). Estimates suggest that over half of all women experience harassment at work (Ilies, Hauserman, Schwochau, \& Stibal, 2003), 70\% of college women report harassment (Buchanan, Bergman, Bruce, Woods, \& Lichty, 2009; Paludi \& Paludi, 2003), and 95\% of high school girls report sexual harassment (Ormerod, Collinsworth, \& Perry, 2008). Sexual harassment also comes from a variety of perpetrators and is present in a variety of settings. For example, targets report harassment from peers, bosses, and subordinates (DeSouza, 2011), random strangers on the street, and people of the same or opposite sex (Street, Gradus, Stafford, \& Kelly, 2007). 
Sexual harassment can adversely affect the academic and mental wellbeing of students at university level (Huerta et al., 2006). Sexual harassment in tertiary institutions of education is widely reported (Monk-Turner \& Turner, 1994; Sharma, 2013; Karimi et al., 2020). Primary reason for the prevalence of sexual harassment is the very nature of university life where males dominate and dictate terms (Dziech and Weiner, 1990). Inappropriate comments or gestures of sexual nature, unwelcomed physical contact such as touching, groping, pinching or sexual assault and rape are common forms of sexual harassment. Since teachers in university are in a position of power, such power may be used in terms of demand of sexual favors, preferential treatment in the class or for securing good grades. The perpetrators may include teachers, students or even administrative staff of the university or educational institution (Sharma, 2013). The prevalence of sexual harassment in education is relatively higher in developing countries owing to weak institutions that have low or absent accountability mechanisms, low budgets of the education sector in general, and lack of gender mainstreaming (Leach, 2013). The teaching faculty in these institutions are underpaid and lack proper training (Beninger, 2013). But it does not mean that sexual harassment is observed only in less developed countries. Cases of sexual harassment are reported in educational institutes of Netherlands, Czech Republic, United States and United Kingdom as well (Rademakers et al., 2008; Borufka, 2010; Haidrani, 2013; Weale, 2014). National Union of Students (NUS) reported that about $33 \%$ of female students experienced sexual harassment on campus in the form of touching and groping. Such harassments or unwelcomed advances of sexual nature are part of 'lad culture' where an attitude of aggression and humiliation of females, jokes of sexual nature or even sexual assault and rape are taken as a pride (Weale, 2014).
There is considerable underreporting of sexual harassment. Studies indicate that only 35 to 45 percent of the victim's reports being sexually harassed. In most of the cases, victims do bear the less severe forms of harassment and report only when the behavior of the harasser passes beyond certain limits or becomes too severe. The reported cases suggest that the problem is much more serious than perceived (Barling, 1996; Barak et al., 1992). To address this problem of under reporting, women were asked to identify which of the behaviors of sexual harassment they had experienced out of a range of actions enlisted. It was observed that the endorsement rates increased 80 to 90 percent (Barak et al., 1992). Faculty at educational institutes are in a position of power owing to the very nature of their job, this contributes to hierarchical power structures between female students and male teachers and professors. This position of power and trust is one of the major contributors to the underreporting of sexual harassment at these institutes (Julie, 2013). Conservative gender roles, honor and shame codes, which may be different for male and female members of the society (Cortina, 2002) and cultural norms that discourage telling others about such behavior by men, may also contribute to underreporting of sexual harassment (Kabaya, 2016). Reluctance to report the abuse is also encouraged by the fact that in many reported incidents, no action is taken against the perpetrators (Leach, 2013; Jamela, 2011). In many of the reported incidents, students were blamed for dressing or behaving provocatively. As a result, students are ashamed or scared, and question their own behavior instead of reporting the incident (Renzetti et al., 2012).

Sexual harassment at university level was ignored by lawmakers for a long period of time. However, there is a renewed focus on the issue in both developed and developing countries alike and new rules and regulations have been introduced. For example, France declared sexual harassment as a 
crime through a legislation in 2012 that is applicable to educational institutes as well. If proven guilty, the culprit can be imprisoned up to three years. South Korea introduced new rules against sexual abuse in universities (The Star/Asia News Network, 2014). Australia introduced Sex and Age Discrimination Legislation Amendment Act 2011 that is applicable to institutes of higher education as well (Australian Human Rights Commission). United States' Equal Employment Opportunity Commission (1999) declared sexual harassment as an effective form of discrimination applicable to higher education institutes as well.

Pakistan introduced Protection against Harassment of Women at Workplace Act 2010, and detailed Policy Guidelines against Sexual Harassment in Institutions of Higher Learning were introduced in 128 public sector universities across Pakistan in January 2011 (Saeed, 2014). The main objective was to provide a secure environment to female students and faculty members working at institutes of higher education where no offensive or hostile behavior by male lecturers, teachers, professors or administrating staff could discourage the active participation of females in learning activities. However, by 2012, anti-sexual harassment regulations were not implemented in most of the public sector universities. Strict measures were taken by Higher Education Commission (here after HEC) to ensure the implementation of policy guidelines regarding sexual harassment since then and universities are bound to establish a specific body dealing with the cases of sexual harassment and submit reports periodically to HEC. In case of non-compliance, universities were threatened with withheld funds (Junaidi, 2012).

There has been a definite increase in the number of cases reported in universities after the enforcement of Protection against Harassment of Women at Workplace Act 2010, but procedural matters still need lot of improvements. A female faculty member working as an assistant professor at Karachi University (KU) reported sexual harassment against a colleague who harassed her twice in the form of unwanted and inappropriate physical contact. The internal inquiry committee of the university, after hearing the case, noted that complainant "should be asked to improve her temperament". It was only after the involvement of the provincial ombudsperson for the protection against harassment of women that the decision was reverted, and another committee passed the verdict that the accused behaved inappropriately with the complainant. While the complaint was filed in 2016, the final judgment came in 2018 after a lot of struggle and humiliation (Sethna, Shah, Masood and Eleazar, 2018). The controller of examinations in a public sector university was forcefully retired by the administration for harassing a female student. There have been more than 40 complaints of sexual harassment between 2011 to 2014, mostly by students against professors in Quaid-e-Azam University (QAU) alone (Saeed, 2014). A male lecturer at Karachi University was found guilty of sexual harassment of a female student by the provincial ombudsman. University administration was advised to take necessary action against the teacher. No action could be taken due to strong lobby of the perpetrator (Shehzad, 2019). Sethna et al. (2018) argued that although the law on sexual harassment is very clear but the implementation mechanism is very weak and in most of the cases, perpetrators get an easy escape. This has been the case for several complaints that include professors, deans and even vice chancellors of universities where either victims are too timid to complain or the complaints could not fetch any results which further discouraged the reporting of such incidents.

Despite the increase in the number of cases reported in institutes of higher education, most of the cases are reported in mainstream print or electronic media. There is a huge gap in literature where things could be understood from student's 
perception. Although there is a technical definition provided by the anti harassment act 2010 and also by policy guidelines for institutes of higher education but it is paramount to know that do students truly understand the term sexual harassment? Are they aware about the term? And how they perceive the term? Is there any gap between students' individual definitions and legislative definitions of sexual harassment which may come from the students' perceptions and construction of sexual harassment? Although universities are advised to form harassment committees, the study tries to assess the extent to which they are active and approachable to the students and how they gauge their effectiveness in terms of cases reported to them and the actions taken. As reported in some of the previous studies, there might be some socio-cultural barriers that are the real constraints in low reporting of the cases. Even if the harassment committee is working effectively, there is a need to understand such sociocultural constraints that undermine the overall process of addressing sexual harassment. The study focuses to address these basic questions: (1) how do students define and respond to different forms of sexual harassment? (2) What factors contribute to particular forms of behavior to be labeled as sexual harassment while others do not? (3) What sociocultural and administrative constraints they face while deciding to report or not to report an incident? (4) And finally, how does an incident of sexual harassment affect the lives of individuals?

\section{Materials and methods}

The study adopted the constructive approach to disentangle the term as sexual harassment. The term is not a social fact that exists independently as an objective reality (Vohlídalová, 2011). It is a culturally and socially constructed phenomenon, like our whole social world is based upon the knowledge people construct influenced by traditions, values, norms, and personal experiences (Charmaz 2003; Gergen 1999). Constructivist research tries to understand how respondents construct their realities in the light of their own experiences and how they give meanings to what they do in their specific social set up (Charmaz, 2003; Gubrium and Holstein, 2003). Analyses of individual definitions, interpretations, and constructions are based upon commonly shared social norms, values, and how they construct power structures in the society (Vohlídalová, 2011).

In-depth interviews of thirty students enrolled at COMSATS University Abbottabad campus were conducted along with two members of harassment committee. The interviews from students were further complemented by self-administered questionnaires that focused on mapping students' experiences with and attitude towards sexual harassment. Application of mixed research design helps understand different perspectives where different components of research complement each other (Vohlídalová, 2011). The data was collected from September to November 2019. The responses were recorded both in English and Urdu language (Pakistan's national language, a preferred mode of communication in otherwise diverse student community coming from different ethnic backgrounds of the country).

Results and discussions

Perception of sexual harassment

Sexual harassment at institutes of higher education existed well before the policy guidelines were introduced, but it was not stressed upon as a social problem and remained invisible. This has been acknowledged even in the policy document issued by the HEC of Pakistan which states that "Sexual harassment in higher education is not a new issue but has until recently been a hidden silent one" (HEC, 2011: p, 4). The introduction of legislation and official definition is still not very well known among students, faculty members and administrative staff. Lack of information and 
awareness is also one of the reasons people do not attribute certain behavior as a form of sexual harassment which otherwise has been declared as sexual harassment in legislation (Vohlídalová, 2011). While analyzing the definitions of the sexual harassment and what students think does not qualify as sexual harassment in their context, it is evident that student's realities are constructed in a certain socio-cultural background with firmly defined boundaries. These boundaries are not constructed by the students themselves; societal norms play an important role in defining such boundaries and give more power to males either students or academic and non-academic staff.

The research drew upon the definitions of sexual harassment provided in the Policy Guidelines against Sexual Harassment in the manual provided by HEC of Pakistan. It uses the basic assumption that sexual harassment is an unwanted behavior that affects the wellbeing of an individual negatively. It does not include obvious and explicit forms of sexual harassment only but also a variety of unwelcomed behavior that may originate out of asymmetrical power structures. The study, aimed to understand, the extent to which the official definitions are mirrored in students' individual definitions, and asked the students to define sexual harassment and explain what they believe falls in category of sexual harassment. This helped to explore the gap between the expert and individual definitions of sexual harassment in the context of university students. There was a huge range of definitions and categorization to what is considered as sexual harassment by students. These definitions were further grouped under four larger sections as shown in the table 1 for ease of discussion.

Table 1: Students' Perception of Sexual Harassment

\begin{tabular}{lc}
\hline \multicolumn{1}{c}{ How to Define Sexual Harassment? } & $\begin{array}{c}\text { Responses in } \\
\text { \% }\end{array}$ \\
\hline Any gender-based discrimination & 37 \\
Any verbal or non-verbal act that makes you & \\
uncomfortable & 23 \\
Physical advances of sexual nature & 17 \\
Being Stalked by Strangers & 10 \\
No Answer & 13 \\
\hline Total & $\mathbf{1 0 0}$ \\
\hline
\end{tabular}

As mentioned in table, majority of the students (37\%) believed that any discrimination based on gender is sexual harassment. This discrimination or "biased behavior" towards females is considered to stem from a position of power. This asymmetric power may exist in the form of student to teacher, student to administration staff or even in case of student to student relationship where male students hold the position of power as against female students owing to social set up where males dominate in every sphere of life. One female student from faculty of business administration reported:

"Male students are preferred to be class representatives by teachers as they can help visit the teacher at odd timings, have less issues of mobility and visit faculty offices more frequently for submission of assignments etc. Intrinsically this provides 
more power to male students as compared to females. This is discrimination by faculty based on gender that puts female students in a position of weakness and portrays men as more powerful; a position that can be exploited."

Another graduate student from faculty of sciences argued:

"Discrimination may not fall directly in sexual harassment, but it gives you a feeling of being weak and vulnerable. Something that is as bad as harassment".

A young student from faculty of business administration reported:

"I have taken a course from a female teacher who was extremely biased against female students. She would snub them, humiliate them and give low grades. Everyone knew it, even boys, that she would like comments from male students and in return they will get good grades. Isn't it sexual harassment? All the female students, keeping quite in the class all the time, nervous and worried about their grades only because of their sex?"

Second category, $17 \%$ of the students, believed that an act can only be considered as sexual harassment if it involves any physical advances of sexual nature e.g. groping, touching, pushing, pinching or all out rape. On further intriguing about verbal advancements or unwelcomed proposals, there were interesting insights.

"Male students do pass some vulgar comments, most of them while walking by a girl but so do girls. It is fun, no one takes them seriously".

This view was shared by many other students as well where they were specifically asked to comment on such behavior in the interviews. In one counter question about why such comments don't make them uncomfortable, one student responded.

"Maybe we are used to such verbal comments and don't feel that much threatened as against physical advancements that actually cross the set boundaries of privacy and is considered offensive".

Such definitions verify and further strengthen the earlier studies on sexual harassment (Vohlídalová, 2011) that it is not the expert definition only, it's about the realities constructed by the students for themselves in their own socio-cultural context.

$23 \%$ of the students considered any act that may include any verbal or non-verbal behavior and can potentially make one uncomfortable is sexual harassment. The notion of asymmetrical power relations to which HEC's policy guideline for sexual harassment (2011) refers to as "an issue of abuse of power, not sex", (p.5) is well understood in this case. Students understand that sexual harassment is any unwanted conduct or any unwanted demand by a person e.g. a faculty member demanding a student to wear lipstick or dress well in front of him to get higher grades. One argued that

"Any faculty member in university has no right to tell me how to dress up. It's an improper way to treat a student".

The asymmetrical power relation is also on display when it comes to how male and female students interact or communicate on campus. One female student in final year of undergrad narrated that,

"Although it is banned but few male students do smoke at student center (student café and tuck shops) and deliberately blow the smoke towards girls. Although apparently, it does not involve anything sexual but implicitly it very much does. Females are considered weak, boys 
know we will not retaliate in any way, neither directly to them nor by reporting to any authority so they keep on doing this. And this is sexual harassment."

On subsequent question of why they would not report, she responded,

"Maybe we are weak. We have heard lots of incidents where boys, disgraced or rejected, throw acid on the face of girls or cause them bad repute. So, it is better to be quite and bear it. But I want to make it clear, this is very much sexual harassment."

Further, stalking is considered as less severe form of harassment or not even a form of harassment by some students. Few (10 percent of the respondents) take it very seriously and consider stalking as an effective form of sexual harassment. Among these, few are those students who don't even consider vulgar comments as harassment. Why is stalking more severe than passing vulgar comments? One of these students responded:

"A stalker is someone very serious about you. He is constantly following you or letting you know that he is there for you. He may harm you more than someone just randomly passing some comments."

So stalking is more worrisome to them and must fall in sexual harassment. The remaining 13\% students either refused to answer or had no idea about how to define sexual harassment.

\section{Prevalence of sexual harassment on campus}

In the previous studies, students who responded positively to the question of whether they had ever faced sexual harassment varied from $2.7 \%$ to about $5-10 \%$. In our study $57 \%$ students declined to answer a direct question of "have you ever encountered sexual harassment on campus?" While $43 \%$ had a positive response about having experienced sexual harassment at university. Out of these, 23\% respondents faced verbal harassment (inappropriate comments, vulgar jokes, whistling and cat calling); $17 \%$ had faced non-verbal harassment (staring, leering at body, stopping the way, following the person); and remaining 3\% faced physical harassment. Physical harassment included touching and holding hand by a male faculty member. A Master of Science (MS) student was approached for intimacy in one of the faculty offices. The others refused to go into the detail of the incident. But it was evident, despite senior students talking more openly about their experience of harassment, that there was still a lot of hesitation and it could be construed that even if any such incident had happened with someone at undergrad level, students will not be willing to talk about it out of fear, shame or embarrassment. Similar responses were observed in the qualitative interviews, students avoided to label their experience as sexual harassment, although certain behavior was unwelcomed. The transgressors in majority (30\%) of these reported cases were students while teaching faculty was also accused in good number (13\%) of cases. Administrative staff was not accused in a single case, the data from the harassment committee also confirmed this trend. This might be because of the reason that most of the administrative tasks are the partial responsibility of the faculty members who do dual job of administration and teaching, so the contact of the students with purely administrative staff is almost none.

Table 2: Dressing Provokes Sexual Harassment

Option

Responses in \% 


\begin{tabular}{lll}
\hline 1 & Strongly Agree & 17 \\
2 & Agree & 20 \\
3 & Neutral & 10 \\
4 & Disagree & 37 \\
5 & Strongly Disagree & 17 \\
\hline
\end{tabular}

In a different context where students were asked whether they had observed or knew incidents of sexual harassment, the positive responses increased significantly. About $70 \%$ of the students had personally observed or knew students in person who were sexually harassed in the campus. The victims were mostly female students. It was reported that in $36.67 \%$ cases, the transgressor was a faculty member. One student reported that

"My best friend was persuaded by a faculty member to visit his office alone if she needed good grade in examination".

Students feel embarrassed or ashamed to admit that they were victims of the crime and may report it by saying that they know someone who had to suffer from it. The high percentage of 70 may actually consist of some self-cases reported as observed cases.

While talking about the socio-cultural norms that construct the definition of sexual harassment, it seemed appropriate to discuss with students what they believe causes sexual harassment. Female students were asked to respond to one statement, "The dressing of female students provokes sexual harassment". They were requested to register their response on Likert Scale. On a scale ranging from strongly agree, agree, neutral, disagree and strongly disagree.

\section{Awareness about sexual harassment committee and reporting of the incidents}

Socio-cultural constraints do play an important role about how students perceive and define sexual harassment but presence of relevant office where students could report the cases of sexual harassment and its effectiveness is one important dimension that can play a significant role in addressing the problem. A formal committee entitled, "Standing Enquiry Committee dealing with Harassment Cases and Abuse of Power" commonly known as "Harassment Committee" was established at COMSATS University Islamabad, Abbottabad Campus in 2011 in the light of policy guidelines provided by HEC of Pakistan. The committee is reconstituted every three years consisting of at least three professors among others. It is mandatory for institutes of higher education to submit the progress report of the committee to HEC periodically. The effectiveness of these official bodies depends upon awareness of students about the presence, ease in reporting and accessibility to students, transparency of the process and verdicts of the reported cases. This in turn develops trust on such official bodies and increases the rate of reporting to a level where the issue of sexual harassment can be addressed effectively. Cases of sexual harassment could also be reported with "Campus Disciplinary Committee" which can then forward the cases of sexual harassment to "Harassment Committee".

The question regarding the existence and working of this body was kept very open and students were asked what they knew about sexual harassment committee at the university. Only about half (51\%) of the students knew about the existence of the harassment committee but none of the respondents had ever visited the office. During the interviews with one of the committee members, it was asserted that to sensitize the students about the significance 
of the issue and to increase awareness, university organizes frequent seminars and information is disseminated among students in class lectures through faculty members. The results of the survey showed that information dissemination through faculty during class lectures was the most effective medium where $37 \%$ of the students got to know about the committee or sexual harassment.

Table 3: Awareness about Sexual Harassment and Harassment Committee

\begin{tabular}{lc}
\hline Statements & $\begin{array}{c}\text { Reponses } \\
(\%)\end{array}$ \\
\hline $\begin{array}{l}\text { Are you aware of Harassment Committee at University? } \\
\text { Did you attend any of the seminars organized by } \\
\text { university on Harassment? }\end{array}$ & 71 \\
$\begin{array}{l}\text { Was the topic ever discussed in the class by any faculty } \\
\text { member? }\end{array}$ & 37 \\
$\begin{array}{l}\text { Did you read the information about the sexual harassment } \\
\text { in university rule book? }\end{array}$ & 27 \\
Are you aware of Harassment at Workplace law 2010 & 0 \\
\hline
\end{tabular}

None of the students knew about the law of sexual harassment at workplace that was so widely discussed in media and provided the foundations for the sensitization of the issue across the country. It was also observed that most respondents who had positive responses about the awareness of the law or disciplinary bodies were students registered in graduate courses. There is a severe lack of awareness as we move to more junior batches of the students, the ones who face the issue more frequently than senior students.
This lack of awareness which contributes partially to lack of trust on such disciplinary bodies results in very low percentage of reported cases. In our study, out of $43 \%$ students who faced sexual harassment $17 \%$ of the students reported the incident to any of the family members. $16 \%$ cases were reported to faculty of the respective department. Only $8 \%$ of the cases were reported to relevant university committee, Campus Disciplinary Committee in this case and only about $2 \%$ ended up in "Harassment Committee".

Table 4: Reporting of Sexual Harassment

\begin{tabular}{lc}
\hline Details of Reported Cases & Reponses (\%) \\
\hline $\begin{array}{l}\text { Reported Cases out of total incidents } \\
\begin{array}{l}\text { Reported to Family Members (mostly mothers and } \\
\text { sisters) }\end{array}\end{array}$ & 43 \\
$\begin{array}{l}\text { Reported to Faculty Members of respective } \\
\text { Department }\end{array}$ & 16 \\
Reported to Campus Disciplinary Committee & 8
\end{tabular}


Analysis of the reported cases to both, Disciplinary committee and Harassment committee showed that in most of the cases where the harasser was a male student, there was an extreme lack of understanding among the accused about when their act will become harassment. For instance, in many cases that concerned primarily with stalking, male students liked the female students and wanted to have a relationship. Since tradition and local norms do not allow open relationships, during proceedings of enquiry committee, the male students were found saying, "I am serious about her and I want to marry her". Another important cultural dimension here is decoding 'NO' from females as 'Yes'. This was observed in number of cases during proceedings of the enquiry, where male students perceived the refusal to their proposal of relationship as traditional shyness of the girls. Student counselling about the sensitivity of the issue and official warning proved to be good enough to address such issues.

In cases where harassment was faced by the respondents themselves, $57 \%$ of the students didn't report to anyone; neither in family nor to any university committee. This comes out of fear of defamation in university in particular and among their own relatives and social circles in general.

"Even your own class fellows blame you that you must have done something to invoke him".

One such victim responded when asked the reason for not reporting the incident. Female students are also worried about their repute on stake if they report such incidents.

"For a traditional society like ours, it can have many long-term consequences for girls, you know?".
Such consequences may vary from an immediate discontinuation of education and denial to any further education to questions on the moral character of the females that can lead to complications during wedding proposals. Such cultural constraints where questions may be raised on the victims own character are one of the very important reasons for not reporting the cases of harassment. Victims prefer to keep it to themselves or discuss the issue with the female members of their family as talking to brothers and fathers would mean a very high chance of discontinuation of studies. Even in cases where female members of the household were informed about any such issue, 7\% of the students reported that their mothers were worried about their safety and advised them not to stay in campus unnecessarily and never participate in any co-curricular or extra-curricular activities.

More serious cases of harassment came from the exboyfriends who were in a relationship with the female students at some point. Refusal to continue the same infuriated the male students and resulted in blackmailing from the male students and in some cases, the family of the female student was approached through 'Facebook' messages or by letters to the female students' homes accusing their moral character and causing shame among friends and relatives. Facebook makes an easy tool to reach all relatives and friends. Most of the reported cases were of such nature where female students had no choice but to report the harassment.

\section{Conclusion}

Results of the study reveal that although students are familiar with the term sexual harassment, confusion still prevails about what can qualify as sexual harassment by definition. As a result, a good proportion of students considered only physically aggressive, unwelcome behavior as sexual harassment. Yet some others consider only rape as 
sexual harassment. Despite of the introduction of Protection against Harassment of Women at Workplace Act 2010 in Institutions of Higher Learning since 2011, awareness about the law and relevant institutional mechanism is less known among the students. As a result, there is a lack of clarity about what falls in sexual harassment, where acts of sexual harassments can be reported, and what possible action can be taken as a result. There is very high prevalence of incidents of sexual harassment primarily faced by female students reportedly both from students and faculty members. However, the percentage of students who have experienced verbal harassment is the highest.

Majority of these incidents is not reported although everyone seems to be aware of such incidents as students discuss it with their friends. The underreporting has three main reasons. First, the mechanism of reporting sexual harassment is not clear to students or they are unaware of any such mechanism's existence in university at all. Consequently, most of the students who are courageous enough to report the incident do not go to sexual harassment committee; they rather report to head of department or faculty members as they seem to be more reliable and easily approachable. Second, most of the students fear that they will not be able to prove it. This is especially true in cases of staring or verbal harassments. In the absence of any clearly defined parameters through which sexual harassment could be reported, this becomes even more difficult. The fear of not being able to prove is even higher in cases where the act is committed by a faculty member or a member of administration. This also comes with the fear of bearing the consequences once they report it. Since faculty members are in position of power as compared to students, so this further ends up in students not reporting the incidents. Third is the societal and cultural norms where students feel ashamed and question their own behavior for any such incident. Instead of reporting the incident of sexual harassment, majority of students reported a self adjustment behavior where they reduced the stay at campus and reduced the chances of contact with the males.

The students who were affected by sexual harassment mostly faced difficulty in concentrating on studies because of the trauma. Further, the students started staying less in campus, they changed the mode of transport, or changed their attitude against the concerned person or with the male students overall. The study concludes that more awareness sessions are required at university level that could bring clarity about sexual harassment both in what qualifies as sexual harassment and what procedures and committees exist at university level to report such incidents, and what consequences the culprits have to face. This probably will require more active involvement of students through seminars and awareness sessions that should involve both male and female students. This might also address the third reason of underreporting i.e. prevailing cultural norms that make girls question themselves instead of reporting the incident.

\section{References}

[1] Adams-Roy, J., \& Barling, J. (1998). Predicting the Decision to Confront or Report Sexual Harassment. Journal of Organizational Behavior, 19(4), 329-336.

Retrieved from http://www.jstor.org/stable/3100150.

[2] Australia Human Rights Commission. (n.d.) Sexual harassment in education. Available at: https://www.humanrights.gov.au/sexualharassment-education, page accessed February 15, 2015.

[3] Barak, A., Fisher, W. A. and Houston, S. (1992). 'Individual difference correlates of the experience of sexual harassment among 
female university students', Journal of Applied Social Psychology, 22, 17-37.

[4] Barling, J., Dekker, I., Loughlin, C., Fullagar, C., Kelloway, E. K. and Johnson, D. (1996). 'Prediction and replication of the personal and organizational consequences of sexual harassment', Journal of Managerial Psychology, 11(5), 4-25.

[5] Beninger, C. (2013) Combating Sexual Harassment in Schools in Sub-Saharan Africa: Legal Strategies Under Regional and International Human Rights Law. African Human Rights Law Journal, 13, pp. 281301.

[6] Berdahl, J. L. (2007). The sexual harassment of uppity women. Journal of Applied Psychology, 92, 425-437.

[7] Borufka, S. (2010) Czech Republic - Study Finds High Levels of Sexual Harassment at Czech Universities. Available at: http://www.wunrn.com/news/ 2010/02_10/02_22_10/022210_czech.htm, page accessed June 25, 2013.

[8] Buchanan, N. T., Bergman, M. E., Bruce, T. A., Woods, K. C., \& Lichty, L. L. (2009). Unique and joint effects of sexual and racial harassment on college students' well-being. Basic and Applied Social Psychology, 31, 267-285.

[9] Charmaz, K. (2003). Grounded theory: Objectivist and constructivist methods. In N. K. Denzin \& Y. S. Lincoln (Eds.), Strategies of qualitative inquiry (pp. 249-291). Thousand Oaks, CA: Sage.

[10] Cortina, L. M., \& Berdahl, J. L. (2008). Sexual harassment in organizations: A decade of research in review. In C. L. Cooper \& J. Barling (Eds.), Handbook of organizational behavior (vol. 1) (pp. 469497). Los Angeles, CA: Sage Publications.

[11] Cortina, L. M., Lonsway, K. A., Magley, V. J., Freeman, L. V., Collinsworth, L. L., Hunter, M., \& Fitzgerald, L. F. (2002). What's gender got to do with it? Incivility in the federal courts. Law \& Social Inquiry, 27, 235-270.

[12] DeSouza, E. R. (2011). Frequency rates and correlates of contra power harassment in higher education. Journal of Interpersonal Violence, 26, 158-188.

[13] Dziech, B., Weiner, L. (1990). The Lecherous Professor: Sexual harassment on campus. Chicago IL: University of Illinois Press.

[14] Education Pakistan (2011). Higher Education Commission Stopping Sexual Harassment at Edu Institutions. Available at: http://pakedu.net/pakistanieducationnews/higher-educationcommission-stopping-sexual-harassment-atedu-institutions/, page accessed September 13, 2013.

[15] Fitzgerald, L. F., Swan, S., \& Magley, V. J. (1997). But was it really sexual harassment? Legal, behavioral, and psychological definitions of the workplace victimization of women. In W. O'Donohue (Ed.), Sexual harassment: Theory, research, and treatment (p. 5-28). Allyn \& Bacon.

[16] Gergen, K. J. (1999). An invitation to social construction. Thousand Oaks, CA: Sage.

[17] Gubrium, J. F., \& Holstein, J. A. (2002). The active subject in qualitative gerontology (pp. 154-171). In G. D. Rowles \& N. Schoenberg (Eds.), Qualitative Gerontology. New York: Springer. 
[18] Haidrani, L. (2013) We Must do More to Fight Sexual Harassment at University. The Independent. Available at: http://www.independent.co.uk/student/stude nt-life/wemust-do-more-to-fight-sexualharassment-at-university-8556855.html, page accessed July 10, 2013.

[19] Huerta, M., Cortina, L. M., Pang, J. S., Torges, C. M., \& Magley, V. J. (2006). Sex and power in the academy: Modeling sexual harassment in the lives of college women. Personality and Social Psychology Bulletin, 32(5), 616-628.

[20] Ilies, R., Hauserman, N., Schwochau, S., \& Stibal, J. (2003). Reported incidence rates of work-related sexual harassment in the United States: Using meta-analysis to explain reported rate disparities. Personnel Psychology, 56, 607-631.

[21] Jamela, C. (2011) Zimbabwe - Sexual Harassment in Higher Education. Available at:

http://www.wunrn.com/news/2011/05_11/05 _16/051611_zimbabwe.htm, page accessed January 11, 2015.

[22] Julie, A. (2013) Sexism and Sexual Harassment in Tertiary Institutions. Gender \& Behaviour, 1, pp. 5237-5243.

[23] Junaidi, I. (2014) Sexual Harassment Allegations Rock Quaid-i-Azam University Again. Available at: http://www.dawn.com/news/1115223, page accessed January 20, 2015.

[24] Karimi, A., White, C. N., Ford, K., Swan, S., \& Spinel, M., Y., (2020). Unwanted advances in higher education: Uncovering sexual harassment experiences in academia with text mining. Information Processing \&
Management, $57(2)$, 102176. https://doi.org/10.1016/i.ipm.2019.102167.

[25] Leach, F. (2013) Corruption as Abuse of Power: Sexual Violence in Educational Institutions. In: G. Sweeney, K. Despota, S. Lindner (EOS). Transparency International, Global Corruption Report: Education. Abingdon, Oxon: Routledge, pp. 88-98.

[26] McLaughlin, H., Uggen, C., \& Blackstone, A. (2012). Sexual harassment, workplace authority and the paradox of power. American Sociological Review, 77, 625647.

[27] Monk-Turner, E., \& Turner, C. (1994). South Korean Labor Market Discrimination against Women: Estimating Its Cost. The American Journal of Economics and Sociology, 53(4), 433-442. Retrieved from http://www.jstor.org/stable/3487187.

[28] Monk-Turner, E., \& Turner, C. (1994). South Korean Labor Market Discrimination against Women: Estimating Its Cost. The American Journal of Economics and Sociology, 53(4), 433-442. Retrieved from http://www.jstor.org/stable/3487187.

[29] Ormerod, A. J., Collinsworth, L. L., \& Perry, L. A. (2008). Critical climate: Relations among sexual harassment, climate and outcomes for high school girls and boys. Psychology of Women Quarterly, 32, 113125.

[30] Paludi, M., \& Paludi, C. (2003). Academic and workplace sexual harassment: A handbook of cultural, social science, management, and legal perspectives. Westport, CT: Praeger Greenwood.

[31] Rademakers, J.J., van den Muijsenbergh, M.E., Slappendel, G., Lagro-Janssen, A.L.M., Borleffs, J.C.C. (2008) Sexual 
Harassment during Clinical Clerkships in Dutch Medical Schools. Medical Education, 5, pp. 452-458.

[32] Renzetti, C. M., Curran, D. J. \& Maier, S. L. (2012). Women, Men and Society (6thed.). Boston: Pearson Education, Inc.

[33] Saeed, F., (February 20, 2014), Antiharassment laws for universities, Pakistan Gender News, retrieved from https://www.pakistangendernews.org/antiharassment-laws-for-universities/ on January 9, 2019.

[34] Schneider, K. T., Pryor, J. B., \& Fitzgerald, L. F. (2010). Sexual harassment research in the United States. In C. L. Cooper (Ed.), Bullying and emotional abuse in the workplace: International perspectives in theory, research, and practice (pp. 245-260). Boca Raton: CRC Press.

[35] Sethna, R, Shah, W. A., Masood, T., and Eleazar, S., (March 22, 2018), Sexual harassment in Pakistan: Breaking the silence on sexism in academia, DAWN, Retrieved from

https://www.dawn.com/news/1396444/sexua 1-harassment-in-pakistan-breaking-thesilence-on-sexism-in-academia on January 9, 2019.

[36] Sharma, Y. (2013) Harassment, Sexual Abuse Corrupts Education Worldwide. University World News. Available at: http://www.universityworldnews.com/article . php?story $=20131001155054992$, page accessed November 18, 2013.

[37] Shehzad, S., (January 4, 2019), Karachi University wants the CM and governor's help to decide what to do in a harassment case, SAMAA TV, Karachi, Pakistan. retrieved https://www.samaa.tv/news/2019/01/karachi -university-wants-the-cm-and-governorshelp-to-decide-what-to-do-in-a-harassmentcase/ on January 9, 2019.

[38] Street, A. E., Gradus, J. L., Stafford, J., \& Kelly, K. (2007). Gender differences in experiences of sexual harassment: Data from a male-dominated environment. Journal of Consulting and Clinical Psychology, 75, 464-474.

[39] The Star/Asia News Network (2014) Universities in South Korea Toughening Rules Against Sexual Harassment Amid Scandals. Available at: http://www.straitstimes.com/ news/asia/eastasia/story/universities-south-koreatoughening-rules-against-sexualharassmentamid-s.

[40] Vohlídalová, M. (2011). The perception and construction of sexual harassment by Czech university students. Sociologický časopis/Czech sociological review, 47(06), 1119-1147.

[41] Weale, S. (2014) Sexual Harassment Rife at UK Universities. The Guardian. Available at:

http://www.theguardian.com/education/2014 /sep/15/sexual-harassment-rife-universitiesnus-survey, page accessed March 15, 2015. 